\title{
WRITTEN AND VISUAL EXPRESSIONS OF AUTHORITY OF FEMALE MONASTIC INSTITUTIONS IN MEDIEVAL LIVONIA: $13^{\mathrm{TH}}$ TO $15^{\mathrm{TH}}$ CENTURIES
}

As of late, there has been steady output of work on the northeastern frontier of the Christian world in the Middle Ages, referred to in its time as Livonia or, since the Fourth Lateran Council of 1215, «the Land of the Mother» (terra Matris) ${ }^{1}$. This body of scholarship has continued to focus on the conquest and conversion of those lands to Christianity, which took place from 1180 to $c$. 1300, with remarkable results. Our understanding of the written culture of these crusades from a variety of perspectives has been enriched. Torben K. Nielsen and Marek Tamm, for example, have illuminated the process of the absorption of Livonia within and its communication to Christendom ${ }^{2}$. Carsten Selch Jensen, Kurt Villads Jensen, and Gustavs Strenga have likewise demonstrated the impact of the crusading idea there, as well as the complex role of memory in shaping regional and international identities within corporations such as the Teutonic Order $^{3}$. Anti Selart has also provided a key study of political

${ }^{1}$ Henry of Livonia. Heinrici Chronicon Livoniae / Ed. by L. Arbusow and A. Bauer (HCL). Hannover, 1955. P. 132 (XIX, 7).

${ }^{2}$ Nielsen T. The Making of New Cultural Landscapes in the Medieval Baltic // Medieval Christianity in the North. New Studies. Turnhout, 2013. P. 121-153; Tamm M. The Livonian Crusade in Cistercian Stories of the Early Thirteenth Century // Crusading on the Edge: Ideas and Practice of Crusading in Iberia and the Baltic Region, 1100-1500. Turnhout, 2016. P. 365-389. ${ }^{3}$ Jensen C. History Made Sacred: Martyrdom and the Making of a Sanctified Beginning in EarlyThirteenth-Century Livonia // Saints and Sainthood around the Baltic Sea: Identity, Literacy, and Communication in the Middle Ages. Kalamazoo, 2013. P. 145-173; Jensen K. V. Crusading at the End of the World. The Spread of the Idea of Jerusalem after 1099 to the Baltic Sea Area and to the Iberian Peninsula // Crusading on the Edge. Ideas and Practices of Crusading in Iberia and the Baltic Region. Turnhout, 2016. P. 153-176; Strenga G. Remembering the Common Past. Livonia as a lieu de mémoire of the Teutonic Order in the Empire // Livland - eine Region am Ende der Welt? Forschungen zum Verhältnis zwischen Zentrum und Peripherie im späten Mittelalter. Köln; Weimar; Wien, 2017. P. 347-370.

(C) G. Leighton, 2021

$\overline{\text { 2021. № } 1 \text { (29). Январь-Июнь }}$ 
relationships amongst institutions such as the military orders, the Church, and the Orthodox world, in addition to the veneration (or, lack thereof) of local saints amongst the Christian population in the eastern Baltic ${ }^{4}$. The study of crusading's impact on the visual culture, particularly the works of Kersti Markus, Anu Mänd, and Merike Kurisoo, has also been investigated recently, with remarkable results, as well as Aleksander Pluskowski's recent book series ${ }^{5}$. Scholars have also begun to investigate the deeper elements of everyday life in the region outside of the annual winter campaigns, with crusaders fighting sub vexilla beate virginis Marie, illuminating the experience of the landed nobility, merchants, and burghers of Livonian cities ${ }^{6}$.

The roles of women and their status in medieval Livonian society remains relatively unexplored until recently, and rarely outside of Estonian and Latvian research circles ${ }^{7}$. Recent studies in the past two decades have likewise appeared in significant amounts on the roles of monastic women in the Middle Ages. They have succeeded in providing a fascinating and

${ }^{4}$ Selart A. 1) Livonia, Rus' and the Baltic Crusades of the Thirteenth Century / Transl. by F. Robb. Leiden, 2015; 2) Meinhard, Berthold, Bernard-kein Heiliger für Livland // CREDO-Christianisierung Europas im Mittelalter 26. Juli bis 3. November 2013. Petersberg, 2013. P. 434-441.

${ }^{5}$ Markus K. 1) Die Christianisierung Livlands aus der Perspektive visueller Quellen // Zeitschrift für Ostmitteleuropa-Forschung. 2015. Bd 64. P. 477-497; 2) The Church on the Borderland. The Impact of Crusading on the Architecture of Gotland and Estonia // Crusading on the Edge... P. 333-364; 3) Visual Culture and Politics in the Baltic Sea Region, 1100-1250 / Transl. by A. Varik. Leiden, 2020; Mänd A. Liturgical Vessels in Medieval Livonia in the Light of Written Evidence // Art and the Church. Religious Art and Architecture in the Baltic Region in the $13^{\text {th }}-18^{\text {th }}$ centuries; Conference Dedicated to the Centenary of Sten I. Karling in Tallinn, Sept. 6-9, 2006. Tallinn, 2008. P. 82-103; Kurisoo M. Sancta Anna ora pro nobis. Images and Veneration of St. Anne in Medieval Livonia // Acta Historiae Artium Balticae. 2007. Vol. 2. P. 18-34; Pluskowski A. Introduction: Multi-Scalar Impacts of Crusading on the Environment of the Eastern Baltic // Ecologies of Crusading, Colonization, and Religious Conversion in the Medieval Baltic. Terra Sacra II. Turnhout, 2019. P. 1-17.

${ }^{6}$ For example: Strenga G. 1) Bidden vor meyner sele. The Dominicans as Intercessors between Townspeople and God in Late Medieval Livonia // Annual of Medieval Studies at Central European University Budapest. 2007. Vol. 13. P. 111-132; 2) Distance, Presence, Absence and Memoria. Commemoration of the Deceased Livonian Merchants outside their Native Cities during the Late Middle Ages // Hansische Geschichtsblätter. Wismar, 2018. Vol. 136. P. 63-92; Mänd A. 1) The Altarpiece of the Virgin Mary of the Confraternity of the Black Heads in Tallinn: Dating, Donors, and the Double Intercession // Acta Historiae Artium Balticae. 2007. Vol. 2. P. 35-53; 2) Table Guilds and Urban Space: Charitable, Devotional, and Ritual Practices in Late Medieval Tallinn // Space, Place, and Motion. Locating Confraternities in the Late Medieval and Early Modern City. Leiden, 2017. P. 21-47.

${ }^{7}$ Põltsam I. Die Frau in der mittelalterlichen livländischen Stadt // Steinbrücke: Estnische Historische Zeitschrift. 1998. Bd 1. P. 43-54; Gassowska M. Scenes from the life of a rich widow. (Reval in the mid-fourteenth century) // Medieval Studies. 2018. Vol. 22. P. 82-97; Mänd A. 1) Memoria and Sacral Art in Late Medieval Livonia: The Gender Perspective // Images and Objects in Ritual Practices in Medieval and Early Modern Northern and Central Europe / Ed. by K. Kodres and A. Mänd. Newcastle upon Tyne, 2013. P. 239-273; 2) Women Shaping Sacred Space: Case Studies from Early $16^{\text {th }}$ Century Lübeck and Tallinn // Hansische Identitäten / Hrsg. von K. Petermann, A. Rasche and G. Weilandt. Petersberg, 2018. P. 83-91; Põlstam-Jürjo I. Lihula isepäised nunad // Läänemaa Muuseumi toimetised / Ed. by E. Russow. Haapsalu, 2015. P. 175-194. 
illuminating re-assessment of the roles played by women and of their place in the medieval world, particularly with respect to female monastic life. The role of monastic women in the production of art, literature, and involvement in religious life has been explored extensively, particularly as of late. However, the majority of these recent studies have been confined to the «central regions» of the medieval world: England, France, Germany, Italy, and the Low Countries ${ }^{8}$.

The present article seeks to add to this outstanding body of work, specifically by providing a discussion of women and authority, but on the periphery of Christendom. With three separate religions, cross-cultural interactions resulting from trade networks, and the presence of international institutions such as the Teutonic Order, Livonia was certainly one of the most diverse regions of the Middle Ages while also existing on the frontier of Christendom. This article will demonstrate this by looking at the representation of women in chronicles, as well as charters, for the history of Livonia from the $13^{\text {th }}$ and into the $15^{\text {th }}$ centuries. It will discuss their roles, particularly as intercessors and economic benefactors, demonstrating that they exerted considerable authority in the region of Livonia in the Middle Ages. As a concluding remark, verbal and visual expressions of this authority will be discussed.

\section{Source Overview for Women of Authority in Medieval Livonia}

The representation of women in the sources for the conquest of Livonia during the $12^{\text {th }}$ and $13^{\text {th }}$ century is extremely scant from the perspective of the main narrative texts. These are, specifically, the Heinrici Chronicon Livoniae (c. 1227), and the Livländische Reimchronik (c. 1290), composed by a member of the Teutonic Order in Livonia9. We only learn of the roles and experiences of women in these texts from a marginal perspective, and almost entirely through the lens of the authors. This is due to the worldview of those authors: their texts intensely focus on the armed conversion of the people of Livonia ${ }^{10}$. Women do still

${ }^{8}$ For example: Seeing and Knowing. Women and Learning in Medieval Europe, 1200-1500 / Ed. by A. B. Mulder-Bakker. Turnhout, 2004; Macy G. The Hidden History of Women's Ordination. Female Clergy in the Medieval West. Oxford, 2007; Crown and Veil. Female Monasticism from the Fifth to the Fifteenth Centuries / Ed. by J. F. Hamburger and S. Marti, transl. by D. Hambuger. New York, 2008; Lindgren E. Sensual Encounters: Monastic Women and Spirituality in Medieval Germany. New York, 2008; Ranft P. Women in Western Intellectual Culture, 600-1500. London, 2008; Women in Medieval Western European Culture / Ed. by L. E. Mitchell. $2^{\text {nd }}$ ed. London; New York, 2011.

${ }^{9}$ HCL; Livländische Reimchronik. Mit Anmerkungen, Namenverzeichnis und Glossar / Ed. by L. Meyer. Paderborn: F. Schönig, 1876. — Both chronicles were translated into English. See: The Chronicle of Henry of Livonia / Ed. and transl. by J. A. Brundage. $2^{\text {nd }}$ ed. New York, 2004; The Livonian Rhymed Chronicle / Ed. and transl. by W. Urban and J. C. Smith. Chicago, 2001. - For the context and authorship of the chronicle, see: Murray A. The Structure, Genre, and Intended Audience of the Livonian Rhymed Chronicle // Crusade and Conversion on the Baltic Frontier, 1150-1500 / Ed. by A. V. Murray. London, 2001.

${ }^{10}$ Gassowska M. Kobieta w średniowiecznych źródłach inflanckich // Kobieta niepoznana na przestrzeni dziejów / Ed. by A. Miączewska, A. Obara-Pawłowska and D. Wróbel. Lublin, 2017. P. 51-74 (especially p. 51). - For the worldview of the two chronicles, see: Johansen P. Die Chronik als Biographie. Heinrich von Lettlands Lebensgang und Weltanschauung // Jahrbücher für Geschichte Osteuropas. 1953. Vol. 1. P. 7-8; Lazda-Cazers R. Landscape as Other in the Livländische Reimchronik // Amsterdamer Beiträge zur älteren Germanistik. 2009. Vol. 65. 
appear in these texts, though, mostly as two categories: as converts, as in Henry's account of the conversion of a man by Theoderic of Treiden (Latv. Turaida) in $1191^{11}$, and as captives or hostages in raids conducted by both Christian and pagan armies ${ }^{12}$. The Reimchronik provides a brief account of Morta, wife of Mindaugas, the first ruler of the Grand Duchy of Lithuania (d. 1263). She counselled Mindaugas to accept Christianity, and maintained her faith when he relapsed to paganism, sending an embassy to the Teutonic Order in Riga ${ }^{13}$. Rasa Mazeika's article on women warriors in the Baltic crusades has demonstrated a more nuanced picture of this perspective, highlighting the instances in women took on combat roles in the $13^{\text {th }}$ and $14^{\text {th }}$ centuries ${ }^{14}$. Women sometimes participated in a military capacity in Livonia, for example in Henry of Livonia's account of a raid in July of 1210 by the Curonians. Upon sounding the war bell, the women and the priests rushed to arms (clerici et mulieri omne ad arma confugiunt). They were also described fighting alongside the Sword Brothers against the Oselians, during an attack on Jerwen (Est. Järva) ${ }^{15}$. This is not unlike an event recorded in Peter von Dusburg's Chronicon terre Prussie, where the women of the city of Elbing (Pol. Elbląg) assisted in defending the city during a raid of Swantopoolk II, Duke of Pomerania, in $1245^{16}$.

World chronicles produced outside of Livonia, such as the Chronicon of Alberic of TroisFontaines (d. 1252), are equally elusive ${ }^{17}$. These authors surely had some knowledge due to the communication of monastic networks such as the Cistercians, and were responsible for disseminating news and information about the «new plantation of the Christian faith» (novella plantatio fidei Christianitatis) on the shores of the eastern Baltic ${ }^{18}$. One exception is the chronicle of the Franciscan monk, Albert of Stade (d. 1256) ${ }^{19}$. He did write that that Adolf IV, Count of Holstein (d. 1261), took his wife, Heilwig von der Lippe (d. 1250), with him on his crusade

P. 183-209; Wüst M. Studien zum Selbstverständnis des Deutschen Ordens im Mittelalter. (Quellen und Studien zur Geschichte des Deutschen Ordens. Bd 73). Weimar, 2013. P. 63.

${ }^{11}$ HCL. P. 5 (I, 10).

${ }^{12}$ HCL. P. 28 (IX, 5), 52 (XI, 5), 53 (XI, 5), 60 (XII, 2), 64 (XII, 6), 70 (XIII, 4), 72 (XIII, 5), 78 (XIV, 6), 82 (XIV, 10), 85 (XIV, 11), 86 (XIV, 12), 88 (XV, 2), 94 (XV, 7), 95 (XV, 7), 96 (XV, 7), 97 (XV, 7), 112 (XVI, 8), 114 (XVI, 5), 119 (XVIII, 5), 120 (XVIII, 6), 124 (XIX, 3), 125 (XIX, 3), 126 (XIX, 3), 133 (XIX, 8), 134 (XIX, 9 \& 11), 135 (XX, 2), 136 (XX, 3), 138 (XX, 5 \& 6), 145 (XXI, 5), 146 (XXI, 7), 150 (XXII, 4), 157 (XXIII, 3), 158 (XXIII, 5), 159 (XXIII, 5 \& 6), 160 (XXIII, 7), 164 (XXIII, 8), 166 (XXIII, 9), 167 (XXIII, 9), 168 (XXIII, 10), 170 (XXIV, 2), 175 (XXIV, 4), 193 (XXVII, 1), 194 (XXVII, 1), 204 (XXVIII, 6), 205 (XXVIII, 6), 209 (XXIX, 3), 216 (XXX, 1), 220 (XXX, 5).

${ }^{13}$ Livländische Reimchronik. P. 82, 146-148. — Also see: Mazeika R. Nowhere was the Fragility of their Sex Apparent: Women Warriors in the Baltic Crusade Chronicles // From Clermont to Jerusalem: The Crusades and Crusader Societies 1095-1500. Selected Proceedings of the International Medieval Congress, University of Leeds, 10-13 July 1995 / Ed. by A. V. Murray. (International Medieval Research. Vol. 3). Turnhout, 1998. P. 240-241, for accounts in the Reimchronik of women participating in battle and providing assistance.

${ }^{14}$ Mazeika R. Nowhere... P. 229-248.

${ }^{15}$ HCL. P. 76 (XIV, 5); 166 (XXIII, 9).

${ }^{16}$ Mazeika R. Nowhere... P. 229-234.

${ }^{17}$ Tamm M. Communicating Crusade. Livonian Mission and the Cistercian Network in the Thirteenth Century // Ajalooline Ajakiri (Historical Magazine). Tartu, 2009. Vol. 129/130. P. 341-372.

${ }^{18}$ For example, see: Tamm M. The Livonian Crusade... P. 365-389.

${ }_{19}$ Plechl H. Albert von Stade // Neue Deutsche Biographie 1. 1953. P. 136. URL: https://www. deutsche-biographie.de/pnd118844644.html\#ndbcontent 
to Livonia in the summer of $1238^{20}$. Heilwig was the granddaughter of the prolific crusader, Bernard II zur Lippe (d. 1224), the first abbot of the monastery at Dünamünde (Daugavgriva, Latvia), and the first bishop of Semigallia ${ }^{21}$. Heilwig is also mentioned in the anonymous Holsteinische Reimchronik, composed in the $15^{\text {th }}$ century, which states that she accompanied her husband on many journeys (sin vorstinne gink mid eme in vromede lant) ${ }^{22}$. We thus gain a small window into the experience of a noblewoman of the $13^{\text {th }}$ century who journeyed to Livonia with her husband. What she did there is unknown, though. She may have visited the monastery founded by her grandfather before going on to the city of Riga, where she would have visited the cathedral of the Virgin Mary (built in 1211), and the other churches in the new Christian colony in the north. She could have also visited the altar of the Holy Cross in the Riga Cathedral, which likely existed in the church from the time of its foundation, in addition to venerating local saints such as the first bishops of Livonia, Meinhard of Üxküll (d. 1196) and Berthold of Loccum (d. 1198) ${ }^{23}$. As has been outlined in the work of Maja Gąssowska, the practice of visiting shrines may have formed an element of the crusade experience throughout the $13^{\text {th }}$ century, though the sources for such activities are not traceable until later, in the $14^{\text {th }}$ century ${ }^{24}$. Heilwig is not present in any of the charters issued in the Livonia during the year of her husband's crusade, though she is mentioned in a charter of 1238 confirming his departure Livonia and founded various monastic houses for women ${ }^{25}$.

${ }^{20}$ Annales Hamburgenses / Ed. by J. M. Lappenberg. Hannover: Hahn, 1859. (Monumenta Germaniae Historica. Scriptores 16). P. 384 («Anno Domini 1238. Comes Adolfus cum uxore sua Heilewiga Livoniam ivit»).

${ }^{21}$ For Bernard's career in Livonia: HCL. P. 88 (XV, 1), 92 (XV, 4), 141 (XXI, 1), 142 (XXI, 2), 146 (XXII, 1); Master Justinus. Das Lippiflorium. Ein westfälisches Heldengedicht aus dem dreizehnten Jahrhundert / Hrsg. von Hermann Althof. Leipzig: Theodor Weicher, 1900. — Bernard was commemorated for his missions to Livonia and role in the development of the church there. See: Dorow W. Denkmäler alter Sprache und Kunst. Vol. 2. Berlin: Paul'sche Buchandlung, 1827. P. 135. - Also see: Tamm M. The Livonian Crusade... P. 374.

${ }^{22}$ Holsteinische Reimchronik / Ed. by L. Weiland. Hannover: Hahn, 1877. P. 625 (lines 568-573). The chronicle is written in Middle Low German. See: Frenz T. Die Holsteinische Reimchronik // Archiv für Kulturgeschichte. 1991. Vol. 73. P. 253-264.

${ }^{23}$ For the architectural history of the Riga Cathedral (Riga Dom), see: Jähnig B. Die Anfänge der Sakraltopographie von Riga// Studien über die Anfänge der Mission in Livland. Sigmaringen, 1989. P. 135-136. - For the altar of the Holy Cross, see: Bruiningk H. von. 1) Die Altäre der Domkirche zu Riga im Mittelalter / Sitzungsberichte für Geschichte und Alterthumskunde der Ostseeprovinzen Russlands aus dem Jahre 1901. 1902. P. 8-12; 2) Die Frage der Verehrung der ersten livländischen Bischöfe als Heilige / Sitzungsberichte... 1902. 1903. P. 3-36. - For more recent studies, see: Hucker B. Zur Frömmigkeit von Livlandpilgern und Ordensrittern // Die Spiritualität der Ritterorden im Mittelalter. Toruń, 1993. P. 111-131 (especially p. 117-119); Selart A. Meinhard, Berthold, Bernard... P. 434-441.

${ }^{24}$ Levāns A. War Riga eine 'heilige' Stadt im Mittelalter? Religiosität, Pilger und der urbane Raum: Riga in der Wahrnehmung des europäischen Stadtbürgertums // Starptautiska konference 'Hanza vakar - Hanza rīt'. (International conference 'Hansa yesterday - Hansa tomorrow). Riga, 2001. P. 53-81; Gassowska M. Der Anteil der Bürger aus den norddeutschen Städten an den Pilgerreisen nach Riga im 13. Jahrhundert // Wallfahrten in der europäischen Kultur: Tagungsband Príbram, 26.-29. Mai 2014. Frankfurt am Main, 2006. P. 147-166.

${ }_{25}$ Hamburgisches Urkundenbuch. Bd 1 (786-1300) / Hrsg. von J. M. Lappenberg. Hamburg: Perthes, Besser \& Mauke, 1842. P. 437-438 (Nr 509), 451 (Nr 533). 
Only one instance in the edited material appears involving a woman, crusading, and monastic life. This is a series of charters issued by Henry III Borwin of Mecklenburg in the early 1270s, which refer to a woman who was originally born in Livonia to non-Christian parents, and taken to Germany to be converted and serve as a nun. We do not know her name, but she is first recorded in a charter issued by Henry, who was on crusade in Livonia around 1269-1270. His campaign may be recorded in the Reimchronik, following the death of Otto von Lutterberg, Landmeister of the Teutonic Order, at the Battle of Karuse (16 February 1270). In any case, upon his return from crusade, Heinrich recounted in a charter «in the middle of a battle with the pagans we seized a small maiden from the edge of the sword» (inter mediam stragem paganorum ancillulam quondam ex ore gladii rapuimus $)^{26}$. This young girl was then given to the monastery at Rehna, in Mecklenburg-Vorpommern. An indulgence was issued for Rehna in $1268^{27}$, and later, in 1270 , when Henry granted more lands to it, he again referred to the captured Livonian woman. This time she appeared as «our beloved, adopted daughter, of pagan parents» (dilecta filia nostra adoptiua de paganis parentibus generata). She was involved in an exchange of land in that year ${ }^{28}$.

Outside of the examples of Heilwig, the women mentioned in the Chronicle of Livonia and the Livonian Rhymed Chronicle, and the anonymous woman captured in 1270, it is clear that women are scarcely mentioned in the narrative texts for the history of Livonia. However, they did manage to figure into some important narrative texts and exert their authority, particularly royal women who accompanied their husbands to Livonia. Monastic women and their communities, however, are not mentioned in these texts, so one must turn to the extensive legal evidence for medieval Livonia to examine their roles and their expressions of authority.

Charters provide a much more nuanced glimpse into the everyday experience and transactions of women, particularly abbesses and nuns. We see a variety of information in them that provide insight into the status, functions, and perception of religious women on this frontier region from a variety of perspectives, including social, religious, and economic ones, which form the foundation of the present article. These sources will be the main base of this article.

\section{INTERCESSORS AND LANDOWNERS: Roles of Monastic Women in Medieval Livonia}

From the $14^{\text {th }}$ century, the importance of nuns and abbesses as intercessors becomes quite clear throughout Europe ${ }^{29}$. We can see this in the increase in the donations to female religious houses in Livonia. Already in the early $14^{\text {th }}$ century, the nuns of the cloister of St. Michael in Reval and the Cistercian nunnery had their privileges and territories in Estonia confirmed by Eric VI Menved, King of Denmark, in May of $1307^{30}$. The donation was given to them for

${ }^{26}$ Liv-, Esth-, und Culrändisches Urkundenbuch nebst Regesten (LUB), Abteilung I, Bd. 1. / Hrsg. von F. G. von Bunge. Reval: Kluge \& Strohm, 1853. Col. 531-532 (Nr 149).

${ }^{27}$ Meklenburgisches Urkundenbuch. Bd 2: 1251-1280 / Hrsg. von dem Verein für Meklenburgische Geschichte und Alterthumskunde. Schwerin: Siller'schen Hofbuchhandlung, 1864. P. 341 (Nr 1137). - For the history of the monastery, see: Lisch G. Ueber die Kirche und das Kloster zu Rehna // Jahrbucher des Vereins für Mecklenburg-Vorpommern. 1850. Vol. 15. P. 289-305.

${ }^{28}$ Meklenburgisches Urkundenbuch. Bd 2: 1251-1280. P. 411 (Nr 1226).

${ }^{29}$ Hamburger J., Suckale R. Between this World and the Next. The Art of Religious Women in the Middle Ages // Crown and Veil... P. 77, 119.

${ }^{30}$ Schmid T. Erik Plovpennig, St. Wentzel und das Nonnenkloster zu Reval // Beiträge zur Kunde Estlands. 1938. Bd 21. P. 123-146 (especially p. 135-137). 
the good of the Danish kingdom and out of a desire «to protect the holy and reverent places out of the love for God» (est honore, loca religiosa et sancta pro Dei amore et reverential confovere). The nuns received land rights (alodia et uncos), and it was forbidden for anybody to impede on these donations. The privileges were renewed by Eric in July of $1307^{31}$, and by the bishop of Reval, Henry, in $1309^{32}$. It is implied that, by receiving these grants of land, the nuns would pray on behalf of the king and his successors.

We also have more personal examples that demonstrate the perception of these institutions by the urban population. For example, in September of 1343, Olav of Roskilde, bishop of Reval (d. 1350), issued a decree concerning a vicarage in the church of St. Michael in Reval, the Cistercian nunnery mentioned above. This vicarage was established by Johann Lange, a citizen of Reval (Johannes Lange, cives Revaliensis). In the decree it was stated that the nuns and abbess of the monastery would pray for Johann, his wife, Elizabeth, and his children at the altar of the Holy Cross in the church ${ }^{33}$. Aside from this specific example, the monastery of St. Michael in Reval continued to receive royal patronage from the Danish kings throughout the $14^{\text {th }}$ century. Further donations to nunneries can be seen throughout the $14^{\text {th }}$ century. For example, Bartholomeus of Thiesenhausen, in his will of 6 May 1397, gave 1 mark to the sisters of the Cistercian monastery of St. Katherine in Dorpat, as well as a gift of 3 marks to Gertrude Holsten, a nun in the same monastery ${ }^{34}$.

By the $15^{\text {th }}$ century, the role of nuns and abbesses as intercessors appears with more regularity in the legal evidence for Livonia. One example can be seen in a donation from 20 November 1429, when Cord Visch, councilman of the city of Riga, donated a total of 12 marks to female religious houses in his last will and testament. That one of these donations was for prayers for his soul (dat ze Gode vor my bidden) speaks to the intercessory nature of female monastic communities. He also donated 10 marks to the Brigittine house in Reval, again for prayers to be said in his name ${ }^{35}$.

Monastic communities of women also issued their own charters and outlined their role as intercessors in the society of medieval Livonia. Here, we can take the example of a document issued by Margaret Engelkens, the abbess of the nunnery of St. Mary Magdalene in Riga, in March of $1434^{36}$. The document is the confirmation of a considerable donation of Hertwig Segefried, a councilman of the city of Riga, in which he founded an altar dedicated to St. Bernard in the church and gave 50 Rigan marks to the nuns, on the stipulation that he and his successors be commemorated in perpetuity. The text is a rare glimpse of the specific details for how Hertwig and his ancestors would be commemorated by the monastic community there. For the foundation of the vicarage to St. Bernard, Margaret received an annual rent of 3 Rigan marks and was obliged to maintain a perpetual mass in the newly-constructed vicarage for Hertwig. He also left large donations in the stipulation that the nuns would

${ }^{31}$ LUB I/1. Cols. 39-44 (Nr 623-626).

${ }^{32}$ LUB I/1. Col. 43-44 (Nr 627).

${ }^{33}$ LUB I/1. Col. 368 (Nr 819).

${ }^{34}$ Livländische Güterurkunden (aus den Jahren 1207 bis 1500) / Hrsg. von H. von Bruiningk and N. Busch. Riga: W.F. Häcker, 1908. P. 170-172 (Nr 147), here: p. 171.

${ }^{35}$ LUB I/7 / Hrsg. von Hermann Hildebrand. Riga: J. Deubner, 1881. P. 244-246 (Nr 372).

${ }^{36}$ Arbusow L. (Sr). Livlands Geistlichkeit vom Ende des 12. bis in 16. Jahrhundert // Jahrbuch für Genealogie, Heraldik und Sphragistik 1901 / Hrsg. von der Kurländischen Gesellschaft für Literatur und Kunst. Mitau: J. F. Steffenhagen \& Son, 1902. P. 64. 
pray for him and for his wife in the morning and in the evening, as well as on major feast days $^{37}$. Much like in other regions of the medieval world, then, it appears that this example demonstrates that the intercessory functions of monastic communities were quite in line with main trends in Europe. The example here also provides a rare glimpse into the function of women as communicators, as it is one of the only documents issued by a monastic woman that has been preserved and edited.

Donations to female monastic communities in Riga were not limited to male benefactors, however. One unique example is the testament of Elisabeth of Putbus, wife of Albrecht Andersson, a knight. The will was written down on 24 February $1444^{38}$. At 2,000 Rigan marks, it is one of the largest donations to a female monastic community preserved in the available source material. Elisabeth made this donation to the house of the Birgittine cloister of Mariendal, near Reval. Founded in 1407, it was one of the most important convents in the region and a recipient of many donations from the local burghers, through whose support it managed to grow into the largest monastic complex in Estonia by the $15^{\text {th }}$ century ${ }^{39}$ Elisabeth also left 100 Rigan marks to Margaret of Grantschen, butensuster of the Mariendal monastery, and 100 Rigan marks to the nunnery of Sonnenschein on the island of Gotland ${ }^{40}$. She also left considerable sums to other individuals and monasteries. Elisabeth's will also reflects the ways in which individuals, particularly women, communicated and expressed their piety in Livonia in the middle of the $15^{\text {th }}$ century. Throughout her will, Elisabeth repeatedly expresses the difference between her earthly life and heaven. In the first line of her will, she gives her soul to the Almighty, her body to the earth (In erste so bevele ik myne sele dem almechtigen Gode, mynen liicham der erden $)^{41}$. This frames the entirety of her donation, the first recipient being the cloister of the Birgittines at Mariendal. Elisabeth's donation also involved the collecting money owed to her by the Livonian Order and its master, Heinrich Vinke von Overburgen (d. 1450) $)^{42}$.

The Teutonic Order was also involved in donations to the female monastic communities of Livonia in the $15^{\text {th }}$ century, particularly the monastery of Mary of Magdalene in Riga. In this light, the role of these communities as significant intercessors in Livonia applies to corporations, not just individuals. This can be further used to study collective understandings of piety and group image, a topic with extensive research on the Teutonic Order in Prussia in the $13^{\text {th }}$ to $15^{\text {th }}$ century. A particularly strong example in the context of religious life in medieval Livonia can be seen in a document issued by Johann Kerssenbrugge (d. 1453), a priest, scribe, and doctor in the Livonian Branch of the Teutonic Order, which was issued

${ }^{37}$ LUB I/8 / Hrsg. von Hermann Hildebrand. Riga: J. Deubner, 1884. P. 456-457. (Nr 782).

${ }^{38}$ LUB I/10 / Hrsg. von Hermann Hildebrand and Philip Schwartz. Riga: J. Deubner, 1896. P. 7-8 (Nr 17).

${ }^{39}$ For a background to the building history, see: Arbusow L. (Sr). Livlands Geistlichkeit vom Ende des 12. bis in 16. Jahrhundert // Jahrbuch für Genalogie, Heraldik und Sphragistik 1911, 1912 \& 1913 / Hrsg. von der Genealogischen Gesellschaft der Ostseeprovinzen zu Mitau. Mitau: J. F. Steffenhagen \& Son, 1914. P. 352-353.

${ }^{40}$ For Margaret, see: Arbusow L. (Sr). Livlands Geistlichkeit vom Ende des 12. bis in 16. Jahrhundert // Jahrbuch für Genealogie, Heraldik und Sphragistik 1901 / Hrsg. von der Kurländischen Gesellschaft für Literatur und Kunst. Mitau: J. F. Steffenhagen \& Son, 1902. P. 64.

${ }^{41}$ LUB I/10. P. 8 (Nr 15).

${ }^{42}$ LUB I/10. P. 8 (Nr 15). 
on 8 July $1445^{43}$. Johann established an altar of St. Margaret in the Church of the Nuns of Mary Magdalene in Riga, with stipulations that, following his death, the nuns would perform a perpetual mass in his memory. As has been examined in the work of Gustavs Strenga, Johann's donation is extremely valuable for studying the perceptions of memory, commemoration, and group identity of the Teutonic Order in Livonia. The decree reflects the complex process in which individual and collective memories intertwined, while also applying to the Order's continued campaigns against unbelievers (in this case Russians, Lithuanians, and even Turks $)^{44}$. The nuns were requested to pray and sing masses for the Order and its armies ${ }^{45}$.

Johann specified that the altar be dedicated St. Margaret, but also in honor of key patron saints of the Teutonic Order. The first to be named were God and the Virgin Mary (Gode tho lave und tho ehren syner leven moder Marien), followed by St. Matthew the Apostle, and St. Procopius. Except for the Virgin Mary, these saints were minor in the Teutonic Order's monastic calendar ${ }^{46}$. St. Procopius, a $4^{\text {th }}$-century martyr and hermit, is not included in the Order's calendar. While a $14^{\text {th }}$-century missal from Riga does commemorate the feast of St. Matthew the Apostle, this saint was very sparsely present in Livonia from the perspective of church dedications ${ }^{47}$. Their inclusion in Johann's donation is more than likely a reflection of his individual devotion, couched within the strong Marian identity of the Teutonic Order. This veneration lasted throughout the Order's history in Livonia, from the $13^{\text {th }}$ and into the $16^{\text {th }}$ century ${ }^{48}$. The masses carried out at the altar were to continually pray for the soul of Johannes, his Order, the Grand Master, and the souls of all other brethren ${ }^{49}$. With respect to the abbess and sisters, they were given the responsibility

${ }^{43}$ Arbusow L. (Sr). Livlands Geistlichkeit... 1901. P. 81. — Also see: LUB I/5. / Hrsg. von F. G. von Bunge. Riga: Kymmel, 1867. Cols. 987-988 (Nr 2706), where Johann is described as schreiber und artdzt in a document from April of 1423 concerning an embassy of the Order to Welun.

${ }^{44}$ Maasing M. Infidel Turks and Schismatic Russians in Late Medieval Livonia // Fear and Loathing in the North: Jews and Muslims in Medieval Scandinavia and the Baltic Region. Berlin, 2015. P. 347-388, here: p. 347-353.

${ }^{45}$ Strenga $G$. Remembering the Dead: Collective Memoria in Late Medieval Livonia: PhD Thesis, Queen Mary University of London. 2013. P. 159-171. - For requesting prayers for the Order on its campaigns against enemies, see: LUB I/10. P. 241-243 (Nr 351), here: p. 242.

${ }^{46}$ Die Statuten des Deutschen Ordens nach den ältesten Handschriften / Hrsg. von M. Perlbach. Halle: Max Niemeyer, 1890. P. 2 (St. Mathew the Apostle). — Also see: Nicholson H. Saints Venerated in the Military Orders // Selbstbild und Selbstverständnis der geistlichen Ritterorden im Mittelalter. Toruń, 2005. P. 91-106.

${ }^{47}$ Heine $W$. Hagiologisches aus Alt-Livland. Studien und Analekten der Heiligenverehrung in Liv-, Est- und Kurland vom Beginn des 13. Jahrhunderts bis auf die Gegenwart von einem Livländer // Der Katholik. Bd 27. 1903. P. 322; Heine W. Hagiologisches aus Alt-Livland von einem Livländer // Der Katholic. Bd 32. 1905. P. 224-225.

${ }^{48}$ Nicholson H. Saints Venerated... P. 100-101. - For the Marian identity of the Teutonic Order, a field studied extensively, see the recent publications of: Wüst $M$. Studien zum Selbstverständis... P. 14-20; Hess C. Himmelskönigin und Geburtshelferin. Marienverehrung im spätmittelalterliche Preussen // Cura animarum. Seelsorge im Deutschordensland Preussen. Köln; Weimar; Wien, 2013. P. 185-199. - For the Marian identity of the Teutonic Order in Livonia at the turn of the $16^{\text {th }}$ century, see: Kreem J. Crusading Traditions and Chivalric Ideals: The Mentality of the Teutonic Order at the Beginning of the Sixteenth Century / Crusades. 2013. Vol. 12. P. 233-250 (especially p. 241-244).

${ }_{49}^{4}$ LUB I/10. P. 97 (Nr 150). 
for choosing subsequent replacement priests to continue the prayer obligations ${ }^{50}$. A similar parallel can be seen in a document of Heinrich Vincke von Overberg, issued in July of 1447. The document stipulates that the nuns of the Cistercian abbey of Riga, who received a mill and land on the island of Dalen in the Düna River (Latv. Daugava), continue to pray for the souls of the Master and of his Order with song and with prayers ${ }^{51}$. This was a phenomenon that is better documented in the Teutonic Order's Prussian territories, particularly in the time of the campaigns against the Lithuanians (the Reisen), but very rarely are glimpses provided for the material concerning Livonia.

The edited material for monastic women in Livonia also has a considerable amount to say regarding territorial donations and land ownership. The ownership of land was one of the primary economic signs of authority in the Middle Ages and served as a way for institutions and individuals to express this authority. This was also true for the monastic communities of women in medieval Livonia. The earliest example comes from a charter of 2 August 1255, when Pope Alexander IV granted the Prioress and Sisters of the Cloister of St. Jacob's Church in Riga permission to establish a Cistercian Nunnery. This was the first nunnery founded in Livonia. Two years later, on 1 May 1257, Bishop Albert of Riga granted this monastery further rights and possessions. The nuns (ancillae Christi Cisterciensis ordinis) received a variety of further land and village donations in and around Riga. Two years after this, Albert granted this nunnery more lands, near the Church of St. Jacob in Riga, in $1259^{52}$. Clearly, already in the $13^{\text {th }}$ century, these nunneries were growing religious institutions in Livonia, which can be studied as a means of examining the economic status of women on the frontier of the Christian world.

By the $14^{\text {th }}$ century, we can see a more continual involvement and representation of female institutions in territorial disputes and acquisitions (mostly in the form of donations by wealthy burghers, knights, and members of the Teutonic Order). In February of 1348, Margaret, Abbess of the Reval nunnery, issued a decree that here cloister had no rights of land use on the islands belonging to the city of Reval, including Nargeiden (Est. Naissaar) ${ }^{53}$. This same Margaret was also active in procuring money for her monastery, and in July of 1354, she successfully sold a mill to the city of Reval for a sum of 40 silver Rigan marks. The purchasers, honorabili viri, domini consuli Revaliensis, enjoyed full legal rights to the mill, in addition to hunting and fishing privileges ${ }^{54}$. The text and the content provides a good example of how female institutions began to demonstrate economic authority in Livonia during the $14^{\text {th }}$ century. To cement this, in June of 1373, Elizabeth, abbess of Cistercian nunnery near Reval, issued a complaint that the city council of Reval had failed to deliver on a rent owed to the monastery ${ }^{55}$.

Throughout the $15^{\text {th }}$ century, grants of land and territorial acquisitions increased, particularly the Cistercian nunnery of St. Jacob in Riga, and St. Michael's convent in Reval. In July of 1429, Christine, abbess of the Cistercian nunnery in Riga, near the St. Jacob's church, received continued support from Dietrich Nagel, a canon of the Riga Cathedral. The document outlines

${ }^{50}$ LUB I/10. P. 97 (Nr 150).

${ }^{51}$ Livländische Guterurkunden (aus den Jahren 1207 bis 1500) / Hrsg. von H. von Bruiningk and

N. Busch. Riga: W. F. Häcker, 1908. P. 300-302 (Nr 327).

${ }^{52}$ Livländische Güterurkunden... P. 35-36 ( Nr 26).

${ }_{53}^{5}$ LUB I/2. / Hrsg. von F. G. von Bunge. Dorpat: Laakmann, 1855. Col. 440 (Nr 886).

${ }^{54}$ LUB I/2. Cols. 595-596 (Nr 952).

${ }^{55}$ LUB I/3. / Hrsg. von F. G. von Bunge. Dorpat: Laakmann, 1857. Cols. 281-282 (Nr 1091). 
the perilous circumstances of Dietrich, mostly concerning his debts that had accrued during a time of plague in Riga. Among his instructions to Conrad, canon of the Riga cathedral, Dietrich wrote that while he could not continue his financial relationship with the abbess, she should still be supported in times of need. The nuns of the Monastery of St. Michael in Reval granted a village to Hans Lechtes, a knight, and his wife, Margaret, in August of 1433. The lease would be held in perpetuity until the death of Hans and Margaret, and included rights to fish and use the waters around the village ${ }^{56}$. The Cistercian nuns in Riga, in June of 1447, received a land grant from Heinrich Vinke involving a mill, which was mentioned above. In addition to the mill, the nuns received lands, land rights, and more territory on the island of Holme (Mārtinsala, Latvia), reflecting the ways in which these institutions could benefit by their relationship to the Teutonic Order ${ }^{57}$. As mentioned above, the land was given not in exchange for economic benefits of the Order, but for prayers and support of the nuns in their campaigns against non-Christians. These lands were used, of course, for the farming activities of the nuns, one example being the garden kept at the monastery of Leal (Est. Lihula) ${ }^{58}$.

Private individuals continued to donate land to nunneries throughout the $15^{\text {th }}$ century, cementing the reputation of female religious houses as recipients of land and their popularity among the local nobility. This can be seen in the donation of Jurgen, a knight of the village of Üxküll (Ikšķile, Latvia) who sold the Cistercian nunnery of Mary Magdalene in Riga the village of Asegall (Krimulda, Latvia) in June of $1457^{59}$. Eleven years later, in June of 1468, the private citizen, Wessel Schetter, pledged and granted the village of Tampsor to the Cistercian nuns in Riga as collateral for a loan of a thousand Riga marks, a considerable sum, and indicative of the possessions held by these institutions in the later $15^{\text {th }}$ century in Livonia ${ }^{60}$.

\section{Expressions and Perceptions of Authority}

The above considerations demonstrate that female religious institutions in Livonia were powerful, both spiritually and economically. They received donations and prayer requests from among virtually all groups of society. This included private individuals, church leaders, and members of the Teutonic Order, from the $13^{\text {th }}$ to the $15^{\text {th }}$ century. This article will elaborate on the visual manifestations of this authority, particularly in the form of the diplomatics of the monasteries, the imagery of their seals, and the visual culture of their buildings.

Diplomatic styling of medieval nunneries and women of authority in medieval Livonia is very scarce. We do not have any documents issued by the women themselves during the $13^{\text {th }}$ century, for example. However, the foundation documents of these institutions and the subsequent grants of land to them at this time do provide a means of examining how contemporaries perceived women of religious authority. Already in the foundation of the Cistercian nunnery of St. Jacob, in Riga, the role of the women is placed within the context of

${ }_{56}^{56}$ LB I/8. P. 416-417 (Nr 709).

${ }^{57}$ Livländische Guterurkunden... P. 301 (Nr 324).

${ }^{58}$ Põltsam-Jürjo I. Lihula Isepäised... P. 182.

${ }^{59}$ Livländische Guterurkunden... P. 342-343 (Nr 382). — See: HCL. P. 44 (X, 14), which documents the construction of the parish church there. For the history of the place name, see: Stikane $V$. Viduslaiku Pergamenta Dokumenti un Lỉbiešu Vietvārdi // Antiquitatis viva. Studia classica. 2019. Vol. 5. P. 171-184 (here: p. 177-178).

${ }^{60}$ Livländische Guterurkunden... P. 398 (Nr 445). 
the conversion of Livonia. The document emphasizes the service of the women to God in its description of them (sanctae Dei genitrices in quo divino obsequio mancipatae). A donation of Albert Suerbeer from 1259 reflects the place of the Cistercian nuns within the providential historical model expressed in the chronicles for this period ${ }^{61}$. In 1257 when Albert Suerbeer, the Archbishop of Riga, confirmed the possessions of the Cistercian nuns, he provides a more thorough analysis of the duties of the nuns. They are described as part of the arms of the church, and one of many orders which had been placed there and flourished, which had extended into the part of the world that was Livonia, the land of people who walked in darkness (Isaiah 9:2). Moreover, they were especially likened to the Virgin Mary, virgin of virgins, highlighting the perception of them as a key religious institution in the land of Mary herself ${ }^{62}$.

In a second confirmation of 1259, Albert likened the house of the nuns to a part of the vineyard of the Lord (vinea Domini que Sabaoth electa), a popular image in the chronicles of the conquest of not just Livonia, but also Prussia ${ }^{63}$. Further north, in Reval, the charters of the kings of Denmark likewise reflect the perception of the nuns of the monastery of St. Michael as a pious and sacred institution, whose prayers were an important commodity for the success of the Danish monarchy in the $14^{\text {th }}$ century. Margaret von Bycken, the abbess of the nunnery of St. Michael's in Reval, issued at least three documents concerning renting of land and of a mill to the city of Reval (discussed above). She issued her documents with a traditional formula, highlighting her status as abbess and head of the convent as Dei gracia ${ }^{64}$.

Only a handful of documents issued by individual abbesses have survived from the $15^{\text {th }}$ century, but the communal aspect can be seen in how the texts are structured. For example, almost all of the documents issued by abbesses in the $15^{\text {th }}$ century proceed with the name of the abbot, followed by that of the prioress, and then a reference to the entire convent. This can be seen in a document of 6 March 1434 issued by Margaret Engelkens, abbess of the Cistercian nunnery of Mary Magdalene in Riga ${ }^{65}$. From this perspective it is difficult to further discern how abbesses and women of religious authority styled themselves in communication with the broader Christian community outside of the examples of the charter evidence. Therefore, it is necessary to look to other examples to see if a clearer picture of female authority can be discerned.

One of the most important examples of this are the seals preserved from the medieval period in Livonia. The collection produced by Baron Robert von Toll, Est- und Livländisches Brieflade provides a rare glimpse into the way women of religious authority styled themselves in medieval Livonia ${ }^{66}$. The seals are preserved and described from the Cistercian nunnery of St. Mary Magdalene in Riga, the Sisters of the Grey Convent in Riga, the Brigittine cloister in Mariendal, the Cistercian nunnery of St. Michael in Reval. The seal of the Abbess of St. Mary

${ }^{61}$ Nielsen T. Providential History in the Chronicles for the Baltic Crusades // The Uses of the Bible in Crusader Sources. Leiden, 2017. P. 361-402.

${ }^{62}$ Livländische Guterurkunden... P. 32 (Nr 25).

${ }^{63}$ Livländische Guterurkunden... P. 35-36 (Nr 26).

${ }^{64}$ LUB I/2. Col. 440 (Nr 886); Col. 595-596 (Nr 952).

${ }^{65}$ LUB I/8. P. 456-457 (Nr 782).

${ }^{66}$ Von Toll R. Est- und Livländische Brieflade. Vierter Theil. Siegel und Münzen der weltlichen und geistlichen Gebietiger über Liv-, Est- und Curland bis zum Jahre 1561. Reval: Kluge \& Ströhm, 1887. 
Magdalene in Riga, from 1336, reflects the individual communication of the institution and the office holder as figures of ecclesiastical and spiritual authority. It depicted a figure of the abbess, standing with a mitre in her right hand and a book in her left hand, most likely a Bible, with the inscription sigillvm abbatisse de Riga $a^{67}$. As argued by Inna Põltsam-Jürjo, this could also reflect the function of the nunneries in producing books ${ }^{68}$. The seal of the Gray Sisters of Riga, dated c. 1352, presents a continuity with the Marian ideology of the Livonian Branch of the Teutonic Order, as well as a parallel to the statue of the Virgin Mary at one of the most important pilgrimage shrines in Prussia during the age of the Reisen, the church at Juditten (Mendelevo, Kaliningrad Oblast, Russia). The seal depicts the Virgin with her crown, standing on a half moon, reflecting the continuity of the ecclesia from the synagoga, as well as the immaculate conception of the Virgin. Latvian historian, Ilona Teplouhova, has produced a recent study of women's seals in Livonia, demonstrating that the seals of women can be seen as a reflection of their power and authority, even in a male-dominated society such as medieval Livonia ${ }^{69}$.

From the perspective of visual culture, Livonia in the medieval period is not as lucky as the southern Baltic region Prussia. Most of the churches and monasteries were destroyed during the Livonian War of $1558-1583^{70}$. Only recently has the visual culture of the medieval Baltic region been addressed systematically, the most recent example being the 2020 monograph of Kersti Markus. Her work addresses the role played in particular by royal and ecclesiastical institutions of Denmark and Sweden in the conquest of the Baltic during the $12^{\text {th }}$ and $13^{\text {th }}$ century with remarkable results on the role of the cult of St. Olav in disseminating political ambitions in the Baltic. Moreover, her final chapter investigates the role of the Cistercians in $13^{\text {th }}$-century Livonia and Estonia, particularly their rapid increase in territories following the foundation of Padise and Falkenau in the $13^{\text {th }}$ century ${ }^{71}$. However, little remains of those buildings that can provide an indication of the visual program of the nunneries themselves.

Instead, one must turn to a later period in the built environment of medieval Livonia and Estonia to study the communication of female authority, specifically the $14^{\text {th }}$ and $15^{\text {th }}$ centuries. The works of Jaan Tamm, Merike Kurisoo, Anu Mänd, and Markus are of key importance in understanding the building programs of nunneries in these regions at this time. Perhaps the most lasting and impactful is the monumentality of the monastic buildings, particularly the convent of St. Michael in Tallinn, one of the few examples of medieval monastic architecture in the region to survive to the present day. Jann Tamm's analysis of the convent of St. Michael in Tallinn and Birgitine nunnery in Mariendal (Pirita) is a case in point. While smaller than other houses in Europe, the technological advancements, such as a hypocaust heating system, speak to the considerable wealth amassed by these institutions in the $15^{\text {th }}$ century ${ }^{72}$. This can also be demonstrated in a considerable amount of donations

${ }^{67}$ Von Toll R. Est- und Livländische Brieflade... P. 113.

${ }^{68}$ Põltsam-Jürjo I. Lihula Ipsepäised... P. 188.

${ }^{69}$ Teplouhova I. Sieviešu zīmogi un sieviešu attēlojums Livonijas vaska zīmogos // Latvijas Universitātes Žurnāls. 2018. Vol. 5. P. 53-66.

${ }^{70}$ For example, see: Arszyński M. Medieval Fortified Architecture in Livonia // The Teutonic Order in Prussia and Livonia: The Political and Ecclesiastical Structures $13^{\text {th }}-16^{\text {th }}$ c. Toruń, 2015. P. 199-224.

${ }^{71}$ Markus K. Visual Culture and Politics... P. 235-351.

${ }^{72}$ Tamm J. Residences of Abbesses in Estonian Monastic Architecture, Based on the Examples of the St. Michael's Cistercian Convent in Tallinn and the Brigittine Convent in Pirita // Baltic Journal 
by patrons of the nuns for building works to be done to the monasteries. For example, Cord Visch, mentioned above, left two marks for building works ( 2 mrc. Tho deme gebuwe) for the nuns of Mariendal in 1429.

It is difficult to discern the specific iconography of major buildings used by the abbesses, though Tamm states that the private residence of the abbess of the St. Michael's convent in Tallinn was decorated with murals and paintings ${ }^{73}$. Rare examples of didactic murals in the region survive in the island churches of Ösel (Saaremaa, Estonia), some of which were painted following the conquest of the island in the winter of 1227. The church of the Teutonic Order at Muhu, dedicated to St. Katherine, for example, had depictions of the apostles and of the Old Testament patriarchs. Therefore, it is not unlikely that the Cistercian nunneries of Livonia would have had similar paintings, perhaps depictions of saints associated with altar foundations of wealthy patrons, in addition to images of the Virgin Mary. However, given the state of the available material culture for the medieval period, this area of the expression of authority by religious women in medieval Livonia remains elusive.

\section{Conclusion}

The above article has provided some general commentary on the roles of religious women in medieval Livonia, particularly nuns and abbesses. It has demonstrated that, similar to their counterparts in Europe, the intercessory functions of female monastic houses in Livonia were a key element of their role in society. Throughout the $14^{\text {th }}$ and $15^{\text {th }}$ centuries in particular, these communities were the focus of extensive donations by members of all levels of Livonian society, including private individuals, church officials, and high-ranking members of the Teutonic Order. Their intercessions were particularly sought for personal salvation, in addition to communal enterprises such as the wars of the Teutonic Order against its enemies. Regarding land ownership, it is also clear that grants of land were important aspects of the economic authority of female monastic houses in Livonia. In addition to giving money for prayers, donors also granted land for nuns to use in exchange for their personal or collective salvation. There were also cases where the nuns themselves exerted their influence and demanded rent payments from their tenants, though this appears to have been an isolated phenomenon in the edited sources.

Finally, the above has also included a discussion of written and visual communications of authority of these institutions. From the perspective of diplomatics, abbesses styled themselves in traditional means in the few available documents that they issued. More revealing is the visual communication of authority. Even in light of the paucity of visual and material culture for medieval Livonia, it is clear that female religious houses communicated their authority within the framework of the Marian ideology of the region. This is most clearly demonstrated in the seals preserved for these houses, which depict the Virgin Mary and Christ, as well as depictions of abbesses themselves holding signs of episcopal authority, as well as holding books. This might also indicate a communication of their intercessory authority. Further examples of visual culture are difficult to trace, such as wall paintings and other forms of media. However, the monumentality of the buildings of Estonia indicate a clear program of expressing power and authority. While the above is a general outline of these

of Art History. Tartu, 2010. Vol. 2. P. 63-95.

${ }^{73}$ Tamm J. Residences of Abbesses... P. 75. 
elements of religious women in Livonia, there is clearly more room for studying these manifestations of authority at a deeper level, and later in the history of medieval Livonia, particularly in the $16^{\text {th }}$ century.

\section{Информация о статье}

Автор: Лейтон, Грегори - кандидат исторических наук, научный сотрудник, Университет Николая Коперника, Торунь, Польша, Orc ID 0000-0002-4203-2313; e-mail: gregjleighton@gmail.com

Заголовок: Written and visual expressions of authority of female monastic institutions in Medieval Livonia: $13^{\text {th }}$ to $15^{\text {th }}$ centuries [Письменные и визуальные свидетельства власти женских монашеских учреждений в средневековой Ливонии: XIII-XV вв.]

Резюме: Статья посвящена роли женщины (в частности, монахини и настоятельницы) в средневековой Ливонии. Принимая во внимание значительное количество работ о крестоносном движении в Балтийском регионе, автор делает акцент на визуальной культуре этого региона, а также переосмысливает положение, которое занимали женщины в средневековом обществе в целом, в контексте концепта «центр - периферия». Автор начинает статью с обзора исторических источников и констатирует скупость конкретных свидетельств о женщинах в повествовательных текстах о крестовых походах в Ливонию, созданных в XIII в. На основе ливонского актового материала приводятся примеры деятельности женщин. В статье рассмотрены способы покровительства монастырям, включая пожертвования в XIII-XV столетиях. В связи с этим, подчеркивается особое отношение к женским монастырям со стороны частных лиц, как представителей церкви, так и членов Тевтонского ордена. Кроме того, проанализирована экономическая составляющая пожертвований, получаемых данными учреждениями, в частности, в виде дарения земель. Наконец, в статье рассматривается саморепрезентация представительниц женских духовных властей с привлечением, не только письменных документов, но и визуальных источников, представленных, в том числе, изображениями на печатях. В статье показано, что женские религиозные структуры вписывали свою власть в контекст марианской идеологии региона. Наиболее отчетливо это прослеживается на сохранившихся печатях, где изображены Дева Мария и Христос, а также сами настоятельницы, держащие знаки епископальной власти, книги. Это может свидетельствовать о передаче ими, как посредниками, заступнической власти.

Ключевые слова: Ливония, женщины в Средние века, история церкви, Тевтонский орден, Северная Европа, позднее Средневековье, исследования средневековья, исследования культуры

\section{Литература, использованная в статье:}

Arzynski, Marian. Medieval fortified architecture in Livonia // The Teutonic Order in Prussia and Livonia: The political and ecclesiastical structures $13^{\text {th }}-16^{\text {th }}$ c. / Ed. Czaja, Roman; Radzimiński, Andrzej. Toruń: Towarystwo Naukowe w Toruniu, 2016. P. 199-224.

Brundage, James (ed.). The Chronicle of Henry of Livonia. New York: Columbia University Press, 2004. 288 p.

Frenz, Thomas. Die Holsteinische Reimchronik. Geschichte eines mittelalterlichen Textes im Spannungsfeld von Wissenschaft und Politik // Archiv für Kulturgeschichte. Berlin: De Gruyter, 1991. Bd 73. P. 253-264. Gąssowska, Maja. Der Anteil der Bürger aus den norddeutschen Städten an den Pilgerreisen nach Riga im 13. Jahrhundert // Wallfahrten in der europäischen Kultur: Tagungsband Príbram, 26.-29. Mai 2004 / Ed. Doležal, Daniel; Kühne, Hartmut. Frankfurt am Main: Peter Lang, 2006. P. 147-166.

Gąssowska, Maja. Kobieta w średniowiecznych źródłach inflanckich // Kobieta niepoznana na przestrzeni dziejów / Red. Miączewska, Anna; Obara-Pawłowska, Anna; Wróbel, Dariusz. Lublin: Wydawnictwo UMCS, 2017. P. 51-74.

Gassowska, Maja. Scenes from the life of a rich widow (Reval in the mid-fourteenth century) // Medieval studies. Gdańsk: Wydawnictwo Uniwersytetu Gdańskiego, 2018. Vol. 22. P. 82-97.

Hamburger, Jeffrey; Susan Marti (eds). Crown and veil. female monasticism from the fifth to the fifteenth centuries. New York: Columbia University Press, 2008. 344 p.

Hess, Cordelia. Himmelskönigin und Geburtshelferin. Marienverehrung im spätmittelalterliche Preussen // Cura animarum. Seelsorge im Deutschordensland Preussen / Hg. Samerski, Stefan. Köln; Weimar; Wien: Böhlau, 2013. (Forschungen und Quellen zur Kirchen- und Kulturgeschichte Orstdeutschlands im Auftrage des Institutes für Ostdeutsche Kirchen- und Kulturgeschichte. Bd 45). S. 185-199. 
Hucker, Bernd Ulrich. Zur Frömmigkeit von Livlandpilgern und Ordensrittern // Die Spiritualität der Ritterorden im Mittelalter / Hrsg. von Zenon Hubert Nowak. Toruń: Uniwersytet Mikołaja Kopernika, 1993. S. 111-131.

Jähnig, Bernhard. Die Anfänge der Sakraltopographie von Riga // Studien über die Anfänge der Mission in Livland / Hrsg. von Manfred Hellmann. Sigmaringen: J. Thorbecke, 1989. S. 123-158.

Jensen, Carsten Selch. History Made Sacred: Martyrdom and the making of a sanctified beginning in Early thirteenth century Livonia // Saints and sainthood around the Baltic Sea: Identity, literacy and communication in the Middle Ages / Ed. Jensen, Carsten Selch; Sands, Tracey Renée; Petersen, Nils Holger. Kalamazoo: Medieval Institute Publications, 2013. (Studies in Medieval and Early Modern Culture. Vol. 54). P. 145-173.

Jensen, Kurt Villads. Crusading at the End of the World. The spread of the idea of Jerusalem after 1099 to the Baltic Sea area and to the Iberian Peninsula // Crusading on the edge: Ideas and practice of crusading in Iberia and the Baltic region, 1100-1500 / Ed. Nielsen, Torben K.; Fonnesberg-Schmidt, Iben. Turnhout: Brepols, 2016. (Outremer. Vol. 4). P. 153-176.

Johansen, Paul. Die Chronik als Biographie. Heinrich von Lettlands Lebensgang und Weltanschauung // Jahrbücher für Geschichte Osteuropas. Stuttgart: Franz Steiner, 1953. Vol. 1. P. 1-24.

Kreem, Juhan. Crusading Traditions and chivalric ideals: The mentality of the Teutonic Order at the beginning of the sixteenth century // Crusades. Aldershot: Ashgate, 2013. Vol. 12. P. 233-250.

Kurisoo, Merike. Sancta Anna ora pro nobis. Images and Veneration of St. Anne in Medieval Livonia // Acta Historiae Artium Balticae. Vilnius: Vilnius Academy of Fine Arts Press, 2007. Vol. 2. P. 18-34.

Lazda-Cazers, Rasma. Landscape as other in the Livländische Reimchronik // Amsterdamer Beiträge zur älteren Germanistik. Leiden: Brill, 2009. Vol. 65. P. 183-209.

Levāns, Andris. War Riga eine 'heilige' Stadt im Mittelalter? Religiosität, Pilger und der urbane Raum: Riga in der Wahrnehmung des europäischen Stadtbürgertums // Starptautiska konference 'Hanza vakar - Hanza rīt’ / Red. Spārītis, Ojārs; Kalniņa, Anita. Riga: Izdevniecība Vārds, 2001. P. 53-81.

Lindgren, Erika Lauren. Sensual encounters: Monastic women and spirituality in Medieval Germany. New York: Columbia University Press, 2008. 210 p.

Maasing, Madis. Infidel Turks and schismatic Russians in Late Medieval Livonia // Fear and loathing in the North: Jews and muslims in Medieval Scandinavia and the Baltic region / Ed. Hess, Cordelia; Adams, Jonathan. Berlin: De Gruyter, 2015. P. 347-388.

Macy, Gary. The hidden history of women's ordination. Female clergy in the Medieval West. Oxford: Oxford University Press, 2007. 260 p.

Markus, Kersti. Die Christianisierung Livlands aus der Perspektive visueller Quellen // Zeitschrift für Ostmitteleuropa-Forschung. Leibniz: Herder-Institut für historische Ostmitteleuropaforschung, 2015. Vol. 64/4. P. 477-497.

Markus, Kersti. The church on the borderland. The impact of crusading on the architecture of Gotland and Estonia // Crusading on the edge: Ideas and practice of crusading in Iberia and the Baltic region, 1100-1500 / Ed. Nielsen, Torben K.; Fonnesberg-Schmidt, Iben. Turnhout: Brepols, 2016. P. 333-364.

Markus, Kersti. Visual culture and politics in the Baltic Sea region, 1100-1250 / Transl. by Aet Varik. Leiden: Brill, 2020. $411 \mathrm{p}$.

Mänd, Anu. Liturgical vessels in Medieval Livonia in the light of written evidence // Art and the church. religious art and architecture in the Baltic region in the $13^{\text {th }}-18^{\text {th }}$ centuries: Conference dedicated to the centenary of Sten I. Karling in Tallinn, Sept. 6-9, 2006 / Ed. Kodres, Krista. Tallinn: Eesti Kunstiakadeemia, 2008. (Toimetised. Eesti Kunstiakadeemia. Vol. 18). P. 82-103.

Mänd, Anu. Memoria and sacral art in Late Medieval Livonia: The gender perspective // Images and objects in ritual practices in Medieval and Early Modern Northern and Central Europe / Ed. Kodres, Krista; Mänd, Anu. Newcastle upon Tyne: Cambridge Scholars Publishing, 2013. P. 239-273.

Mänd, Anu. Table guilds and urban space: Charitable, devotional, and ritual practices in Late Medieval Tallinn // Space, place, and motion. Locating confraternities in the Late Medieval and Early Modern city / Ed. Presciutti, Diana Bullen. Leiden: Brill, 2017. P. 21-47.

Mänd, Anu. The Altarpiece of the Virgin Mary of the confraternity of the Black Heads in Tallinn: Dating, donors, and the double intercession // Acta Historiae Artium Balticae. Vilnius: Vilnius Academy of Fine Arts Press, 2007. Vol. 2. P. 35-53.

Mänd, Anu. Women shaping sacred space: Case studies from Early $16^{\text {th }}$ century Lübeck and Tallinn // Hansische Identitäten / Hrsg. von Kerstin Petermann, Anja Rasche and Gerhard Weilandt. Petersberg: 
Harrassowitz, 2018. (Coniunctiones - Beiträge des Netzwerks Kunst und Kultur der Hansestädte. Bd 1). P. 83-91.

Mazeika, Rasa. Nowhere was the fragility of their sex apparent: Women warriors in the Baltic crusade chronicles // From Clermont to Jerusalem: The crusades and crusader societies 1095-1500. Selected proceedings of the international Medieval congress, University of Leeds, 10-13 July 1995 / Ed. Murray, Alan V. Turnhout: Brepols, 1998. (International Medieval Research. Vol. 3). P. 229-248.

Mitchell, Linda (ed.). Women in Medieval Western European culture. London; New York: Routledge, 2011. $422 \mathrm{p}$.

Mulder-Bakker, Anneke (ed.). Seeing and knowing. Women and learning in Medieval Europe, 1200-1500. Turnhout: Brepols, 2004. 205 p.

Murray, Alan. The structure, genre, and intended audience of the Livonian Rhymed Chronicle // Crusade and conversion on the Baltic frontier, 1150-1500 / Ed. Murray, Alan V. London: Routledge, 2001. P. 235-251.

Nicholson, Helen. Saints Venerated in the Military Orders // Selbstbild und Selbstverständnis der geistlichen Ritterorden im Mittelalter / Hrsg. von Roman Czaja and Jürgen Sarnowsky. Toruń: Uniwersytet Mikołaja Kopernika, 2005. (Ordines Militares. Colloquia Torunensia Historica. Bd 13). P. 91-106.

Nielsen, Torben. The making of new cultural landscapes in the Medieval Baltic // Medieval christianity in the North. New studies / Ed. Salonen, Kirsi; Jensen, Kurt Villads; Jørgensen, Torstein. Turnhout: Brepols, 2013. (Acta Scandinavica. Vol. 1). P. 121-153.

Nielsen, Torben. Providential history in the chronicles for the Baltic crusades // The uses of the Bible in crusader sources / Ed. Lapina, Elizabeth; Morton, Nicholas. Leiden: Brill, 2017. P. 361-402.

Plechl, Helmut. Albert von Stade // Neue Deutsche Biographie. Vol. 1. 1953. P. 136. URL: https://www. deutsche-biographie.de/pnd118844644.html\#ndbcontent

Pluskowski, Aleksander. Introduction: Multi-scalar impacts of crusading on the environment of the Eastern Baltic // Ecologies of crusading, colonization, and religious conversion in the Medieval Baltic. Terra Sacra II / Ed. Pluskowski, Aleksander. Turnhout: Brepols, 2019. (Environmental Histories of the North Atlantic World. Vol. 3). P. 1-17.

Põltsam, Inna. Die Frau in der mittelalterlichen livländischen Stadt // Steinbrücke: Estnische Historische Zeitschrift. Vol. 1. Tartu: Ajalookirjanduse Sihtasutus Kleio, 1998. P. 43-54.

Põltsam-Jürjo, Inna. Lihula Isepäised Nunnad // Läänemaa Muuseumi toimetised / Ed. Russow, Erki. Haapsalu: SA Haapsalu ja Läänemaa muuseumid, 2015. P. 175-194.

Ranft, Patricia. Women in western intellectual culture, 600-1500. London: Palgrave MacMillan, 2008. 279 p. Schmid, Toni. Erik Plovpennig, St. Wentzel und das Nonnenkloster zu Reval // Beiträge zur Kunde Estlands. Tallinn: Estländischen Literärischen Gesellschaft, 1938. Bd 21. P. 123-146.

Selart, Anti. Livonia, Rus' and the Baltic crusades of the thirteenth century / Transl. by Fiona Robb. Leiden: Brill, 2015. (East Central and Eastern Europe in the Middle Ages. Vol. 29). 385 p.

Selart, Anti. Meinhard, Berthold, Bernard-kein Heiliger für Livland // CREDO-Christianisierung Europas im Mittelalter 26. Juli bis 3. November 2013 / Ed. Stiegemann, Christoph; Kroker, Martin; Walter, Wolfgang. Petersberg: Michael Imhof, 2013. P. 434-441.

Stikāne, Vija. Viduslaiku Pergamenta Dokumenti un Lībiešu Vietvārdi // Antiquitas viva. Studia classica. Riga: Latvijas Universitātes Akadēmiskais apgāds, 2019. Vol. 5. P. 171-184.

Strenga, Gustavs. Bidden vor meyner sele. The Dominicans as intercessors between townspeople and God in Late Medieval Livonia // Annual of Medieval Studies at Central European University Budapest. Budapest: Central European University Press, 2007. Vol. 13. P. 111-132.

Strenga, Gustavs. Distance, presence, absence and memoria. Commemoration of the deceased Livonian merchants outside their native cities during the Late Middle Ages // Hansische Geschichtsblätter. Wismar: Callidus, 2018. Vol. 136. P. 63-92.

Strenga, Gustavs. Remembering the common past. Livonia as a lieu de mémoire of the Teutonic Order in the Empire // Livland - eine Region am Ende der Welt? Forschungen zum Verhältnis zwischen Zentrum und Peripherie im späten Mittelalter / Ed. Selart, Anti; Thumser, Mathias. Köln; Weimar; Wien, 2017. (Quellen und Studien zur Baltischen Geschichte. Bd 27). P. 347-370.

Strenga, Gustavs. Remembering the dead: Collective memoria in Late Medieval Livonia: PhD Thesis, Queen Mary University of London. 2013. 274 p.

Tamm, Marek. Communicating crusade. Livonian mission and the cistercian network in the thirteenth century // Ajalooline Ajakiri. Vol. 129/130. Tartu: University of Tartu Press, 2009. P. 341-372. 
Tamm, Jaan. Residences of abbesses in Estonian monastic architecture, based on the examples of the St. Michael's cistercian convent in Tallinn and the Brigittine Convent in Pirita // Baltic journal of art history. Vol. 2. Tartu: University of Tartu Press, 2010. P. 63-95.

Tamm, Marek. The Livonian crusade in cistercian stories of the Early thirteenth century // Crusading on the edge: Ideas and practice of crusading in Iberia and the Baltic region, 1100-1500 / Ed. Nielsen, Torben K.; Fonnesberg-Schmidt, Iben. Turnhout: Brepols, 2016. P. 365-389.

Teplouhova, Ilona. Sieviešu zīmogi un sieviešu attēlojums Livonijas vaska zīmogos // Latvijas Universitātes Žurnāls. Vēsture. Rīga: LU Akadēmiskais apgāds, 2018. Vol. 5. P. 53-66.

Urban, Willam; Smith, Jerry C. (eds). The Livonian Rhymed Chronicle. Chicago: Lithuanian research and studies center, 2001. $134 \mathrm{p}$.

Wüst, Marcus. Studien zum Selbstverständnis des Deutschen Ordens im Mittelalter. Weimar: VDG, 2013. (Quellen und Studien zur Geschichte des Deutschen Ordens. Bd 73). 333 p.

Information about the article

Author: Leighton, Gregory - PhD in History, Research Assistant, Nicolaus Copernicus University, Torun, Poland, Orc ID 0000-0002-4203-2313; e-mail: gregjleighton@gmail.com

Title: Written and visual expressions of authority of female monastic institutions in Medieval Livonia: $13^{\text {th }}$ to $15^{\text {th }}$ centuries

Summary: This article presents a study of how women (specifically nuns and abbesses) were perceived in medieval Livonia. Given the significant increase in accessible academic work on the crusading movement in the eastern Baltic, scholarly considerations of the visual culture of this region, and reconsiderations of the roles played by women in the medieval world in general, this article turns from the central regions of the study of Medieval Europe to the periphery. It begins by providing a historical overview of the sources, commenting on the sparsity of specific representations of women in the narrative texts for the Livonian crusades produced in the $13^{\text {th }}$ century. Following this overview, it analyses the representations of women in the vast amount of charter evidence available for the study of Livonia. The first part of the article looks at the ways these institutions were patronized as a result of their intercessory authority. Looking at donations from the $13^{\text {th }}$ to the $15^{\text {th }}$ century, this article also comments on the ways in which private citizens, church officials, and members of the Teutonic Order viewed these intercessory powers. The second part also considers the economic authority gained by these institutions, particularly in the form of land donations. Finally, this article addresses the ways in which women of authority styled themselves in the written documents and depicted their power in the form of visual media, particularly on seals but also in the form of architecture.

Keywords: Livonia, Medieval Women, Church History, Teutonic Order, Late Medieval, Northern Europe, medieval studies, cultural studies

\section{References:}

Arzynski, Marian. Medieval fortified architecture in Livonia, in Czaja, Roman; Radzimiński, Andrzej (eds). The Teutonic Order in Prussia and Livonia: The political and ecclesiastical structures $13^{\text {th }}-16^{\text {th }} \mathrm{c}$. Torun: Towarystwo Naukowe w Toruniu Publ., 2016. Pp. 199-224.

Brundage, James (ed.). The Chronicle of Henry of Livonia. New York: Columbia University Press, 2004. 288 p. Frenz, Thomas. Die Holsteinische Reimchronik. Geschichte eines mittelalterlichen Textes im Spannungsfeld von Wissenschaft und Politik Politik [The rhymed Chronicle of Holstein. The history of a Medieval text between the conflicting priorities of science and politics], in Archiv für Kulturgeschichte. Berlin: De Gruyter Publ., 1991. Vol. 73. Pp. 253-264. (in German).

Gąssowska, Maja. Der Anteil der Bürger aus den norddeutschen Städten an den Pilgerreisen nach Riga im 13. Jahrhundert [The participation of the burghers from the North German cities on pilgrimages to Riga in the thirteenth century], in Doležal, Daniel; Kühne, Hartmut (eds). Wallfahrten in der europäischen Kultur: Tagungsband Pribram, 26.-29. Mai 2004. Frankfurt am Main: Peter Lang Publ., 2006. Pp. 147-166. (in German).

Gąssowska, Maja. Kobieta w średniowiecznych źródłach inflanckich [Woman in medieval Livonian sources], in Miączewska, Anna; Obara-Pawłowska, Anna; Wróbel, Dariusz (eds). Kobieta niepoznana na przestrzeni dziejów. Lublin: UMCS Publ., 2017. Pp. 51-74. (in Polish).

Gąssowska, Maja. Scenes from the life of a rich widow (Reval in the mid-fourteenth century), in Medieval Studies. Gdańsk: Wydawnictwo Uniwersytetu Gdańskiego Publ., 2018. Vol. 22. Pp. 82-97.

Hamburger, Jeffrey; Susan Marti (eds). Crown and veil. female monasticism from the fifth to the fifteenth centuries. New York: Columbia University Press, 2008. 344 p. 
Hess, Cordelia. Himmelskönigin und Geburtshelferin. Marienverehrung im spätmittelalterliche Preussen [Queen of Heaven and Midwife. Veneration of Mary in Late Medieval Prussia], in Samerski, Stefan (ed.). Cura animarum. Seelsorge im Deutschordensland Preussen. Köln; Weimar; Wien: Böhlau Publ., 2013. (Forschungen und Quellen zur Kirchen- und Kulturgeschichte Orstdeutschlands im Auftrage des Institutes für Ostdeutsche Kirchen- und Kulturgeschichte. Bd 45). Pp. 185-199. (in German).

Hucker, Bernd Ulrich. Zur Frömmigkeit von Livlandpilgern und Ordensrittern [On the religiosity of pilgrims to Livonia and Teutonic knights], in Nowak, Zenon Hubert (ed.). Die Spiritualität der Ritterorden im Mittelalter. Toruń: Uniwersytet Mikołaja Kopernika Publ., 1993. Pp. 111-131. (in German).

Jähnig, Bernhard. Die Anfänge der Sakraltopographie von Riga, in Hellmann, Manfred (ed.). Studien über die Anfänge der Mission in Livland. Sigmaringen: J. Thorbecke Publ., 1989. Pp. 123-158. (in German).

Jensen, Carsten Selch. History made sacred: Martyrdom and the making of a sanctified beginning in Early thirteenth century Livonia, in Jensen, Carsten Selch; Sands, Tracey Renée; Petersen, Nils Holger (eds). Saints and Sainthood around the Baltic sea: Identity, literacy and communication in the Middle Ages. Kalamazoo: Medieval Institute Publications, 2013. (Studies in Medieval and Early Modern Culture. Vol. 54). Pp. 145-173. Jensen, Kurt Villads. Crusading at the End of the World. The spread of the idea of Jerusalem after 1099 to the Baltic sea area and to the Iberian Peninsula, in Nielsen, Torben K.; Fonnesberg-Schmidt, Iben (eds). Crusading on the edge: Ideas and practice of crusading in Iberia and the Baltic region, 1100-1500. Turnhout: Brepols Publ., 2016. (Outremer. Vol. 4). Pp. 153-176.

Johansen, Paul. Die Chronik als Biographie. Heinrich von Lettlands Lebensgang und Weltanschauung [The beginnings of the sacred topography of Riga], in Jahrbücher für Geschichte Osteuropas. Stuttgart: Franz Steiner Publ., 1953. Vol. 1. Pp. 1-24. (in German).

Kreem, Juhan. Crusading traditions and chivalric ideals: The mentality of the Teutonic Order at the beginning of the sixteenth century, in Crusades. Aldershot: Ashgate Publ., 2013. Vol. 12. Pp. 233-250.

Kurisoo, Merike. Sancta Anna ora pro nobis. Images and Veneration of St. Anne in Medieval Livonia, in Acta Historiae Artium Balticae. Vilnius: Vilnius Academy of Fine Arts Press, 2007. Vol. 2. Pp. 18-34.

Lazda-Cazers, Rasma. Landscape as Other in the Livländische Reimchronik, in Amsterdamer Beiträge zur älteren Germanistik. Leiden: Brill Publ., 2009. Vol. 65. Pp. 183-209.

Levāns, Andris. War Riga eine 'heilige' Stadt im Mittelalter? Religiosität, Pilger und der urbane Raum: Riga in der Wahrnehmung des europäischen Stadtbürgertums [Was Riga a Holy city in the Middle Ages? Religiosity, pilgrims and the urban space: Riga in the perception of the European urban bourgeoisie], in Spārītis, Ojārs; Kalniņa, Anita (eds). Starptautiska konference 'Hanza vakar - Hanza rīt'. Riga: Vārds Publ., 2001. Pp. 53-81. (in German).

Lindgren, Erika Lauren. Sensual encounters: Monastic women and spirituality in Medieval Germany. New York: Columbia University Press, 2008. 210 p.

Maasing, Madis. Infidel turks and schismatic Russians in Late Medieval Livonia, in Hess, Cordelia; Adams, Jonathan (eds). Fear and loathing in the North: Jews and Muslims in Medieval Scandinavia and the Baltic region. Berlin: De Gruyter Publ., 2015. Pp. 347-388.

Macy, Gary. The Hidden history of women's ordination. Female clergy in the Medieval West. Oxford: Oxford University Press, 2007. 260 p.

Markus, Kersti. Die Christianisierung Livlands aus der Perspektive visueller Quellen [The christianisation of Livonia from the perspective of visual sources], in Zeitschrift für Ostmitteleuropa-Forschung. Leibniz: Herder-Institut für historische Ostmitteleuropaforschung, 2015. Vol. 64/4. Pp. 477-497. (in German).

Markus, Kersti. The church on the borderland. The impact of crusading on the architecture of Gotland and Estonia, in Nielsen, Torben K.; Fonnesberg-Schmidt, Iben (eds). Crusading on the edge: Ideas and practice of crusading in Iberia and the Baltic region, 1100-1500. Turnhout: Brepols Publ., 2016. Pp. 333-364.

Markus, Kersti. Visual culture and politics in the Baltic sea region, 1100-1250. Leiden: Brill Publ., 2020. $411 \mathrm{p}$.

Mänd, Anu. Liturgical vessels in Medieval Livonia in the light of written evidence, in Kodres, Krista (ed.). Art and the church. Religious art and architecture in the Baltic region in the $13^{\text {th }}-18^{\text {th }}$ centuries: Conference dedicated to the centenary of Sten I. Karling in Tallinn, Sept. 6-9, 2006. Tallinn: Eesti Kunstiakadeemia Publ., 2008. (Toimetised. Eesti Kunstiakadeemia. Vol. 18). Pp. 82-103.

Mänd, Anu. Memoria and sacral art in Late Medieval Livonia: The gender perspective, in Kodres, Krista; Mänd, Anu (eds). Images and objects in ritual practices in Medieval and Early Modern Northern and Central Europe. Newcastle upon Tyne: Cambridge Scholars Publishing, 2013. Pp. 239-273. 
Mänd, Anu. Table guilds and urban space: Charitable, devotional, and ritual practices in Late Medieval Tallinn, in Presciutti, Diana Bullen (ed.). Space, place, and motion. Locating confraternities in the Late Medieval and Early Modern City. Leiden: Brill Publ., 2017. Pp. 21-47.

Mänd, Anu. The Altarpiece of the Virgin Mary of the confraternity of the Black Heads in Tallinn: Dating, donors, and the double intercession, in Acta Historiae Artium Balticae. Vilnius: Vilnius Academy of Fine Arts Press, 2007. Vol. 2. Pp. 35-53.

Mänd, Anu. Women shaping sacred space: Case studies from Early $16^{\text {th }}$ century Lübeck and Tallinn, in Petermann, Kerstin; Rasche, Anja; Weilandt, Gerhard (eds). Hansische identitäten. Petersberg: Harrassowitz Publ., 2018. (Coniunctiones - Beiträge des Netzwerks Kunst und Kultur der Hansestädte. Bd 1). Pp. 83-91. Mazeika, Rasa. Nowhere was the fragility of their sex apparent: Women warriors in the Baltic crusade chronicles, in Murray, Alan V. (ed.). From Clermont to Jerusalem: The crusades and crusader societies 1095-1500. Selected proceedings of the international medieval congress, University of Leeds, 10-13 July 1995. Turnhout: Brepols Publ., 1998. (International Medieval Research. Vol. 3). Pp. 229-248.

Mitchell, Linda (ed.). Women in Medieval Western European culture. London; New York: Routledge Publ., 2011. $422 \mathrm{p}$.

Mulder-Bakker, Anneke (ed.). Seeing and knowing. Women and learning in Medieval Europe, 1200-1500. Turnhout: Brepols Publ., 2004. 205 p.

Murray, Alan. The structure, genre, and intended audience of the Livonian rhymed chronicle, in Murray, Alan V. (ed.). Crusade and conversion on the Baltic frontier, 1150-1500. London: Routledge Publ., 2001. Pp. 235-251.

Nicholson, Helen. Saints Venerated in the Military orders, in Czaja, Roman; Sarnowsky, Jürgen (eds). Selbstbild und Selbstverständnis der geistlichen Ritterorden im Mittelalter. Toruń: Uniwersytet Mikołaja Kopernika Publ., 2005. (Ordines Militares. Colloquia Torunensia Historica. Bd 13). Pp. 91-106.

Nielsen, Torben. The making of new cultural landscapes in the Medieval Baltic, in Salonen, Kirsi; Jensen, Kurt Villads; Jørgensen, Torstein (eds). Medieval christianity in the North. New studies. Turnhout: Brepols Publ., 2013. (Acta Scandinavica. Vol. 1). Pp. 121-153.

Nielsen, Torben. Providential history in the chronicles for the Baltic crusades, in Lapina, Elizabeth; Morton, Nicholas (eds). The uses of the Bible in crusader sources. Leiden: Brill Publ., 2017. Pp. 361-402.

Plechl, Helmut. Albert von Stade, in Neue Deutsche Biographie. Vol. 1. 1953. P. 136. URL: https://www. deutsche-biographie.de/pnd118844644.html\#ndbcontent

Pluskowski, Aleksander. Introduction: Multi-scalar impacts of crusading on the environment of the Eastern Baltic, in Pluskowski, Aleksander (ed.). Ecologies of crusading, colonization, and religious conversion in the Medieval Baltic. Terra Sacra II. Turnhout: Brepols Publ., 2019. (Environmental Histories of the North Atlantic World. Vol. 3). Pp. 1-17.

Põltsam, Inna. Die Frau in der mittelalterlichen livländischen Stadt [The Woman in the Medieval Livonian City], in Steinbrücke: Estnische Historische Zeitschrift. Vol. 1. Tartu: Ajalookirjanduse Sihtasutus Kleio Publ., 1998. Pp. 43-54. (in German).

Põltsam-Jürjo, Inna. Lihula Isepäised Nunnad [Lihula closter stubborn nuns], in Russow, Erki (ed.). Läänemaa Muuseumi toimetised. Haapsalu: SA Haapsalu ja Läänemaa muuseumid Publ., 2015. Pp. 175-194. (in Estonian). Ranft, Patricia. Women in western intellectual culture, 600-1500. London: Palgrave MacMillan Publ., 2008. 279 p. Schmid, Toni. Erik Plovpennig, St. Wentzel und das Nonnenkloster zu Reval [St Wenceslaus and the Nunnery in Reval], in Beiträge zur Kunde Estlands. Tallinn: Estländischen Literärischen Gesellschaft Publ., 1938. Vol. 21. Pp. 123-146. (in German).

Selart, Anti. Livonia, Rus'and the Baltic crusades of the thirteenth century. Leiden: Brill Publ., 2015. (East Central and Eastern Europe in the Middle Ages. Vol. 29). 385 p.

Selart, Anti. Meinhard, Berthold, Bernard-kein Heiliger für Livland [Meinhard, Berthold, Bernard-No Saint for Livonia], in Stiegemann, Christoph; Kroker, Martin; Walter, Wolfgang (eds). CREDO-Christianisierung Europas im Mittelalter 26. Juli bis 3. November 2013. Petersberg: Michael Imhof Publ., 2013. Pp. 434-441. (in German).

Stikāne, Vija. Viduslaiku Pergamenta Dokumenti un Lībiešu Vietvārdi [Medieval parchment documents and livular place names], in Antiquitas viva. Studia classica. Riga: Latvijas Universitātes Akadēmiskais apgāds Publ., 2019. Vol. 5. Pp. 171-184. (in Latvian).

Strenga, Gustavs. Bidden vor meyner sele. The Dominicans as intercessors between townspeople and God in Late Medieval Livonia, in Annual of Medieval studies at Central European University Budapest. Budapest: Central European University Press, 2007. Vol. 13. Pp. 111-132. 
Strenga, Gustavs. Distance, presence, absence and memoria. Commemoration of the deceased Livonian merchants outside their native cities during the Late Middle Ages, in Hansische Geschichtsblätter. Wismar: Callidus Publ., 2018. Vol. 136. Pp. 63-92.

Strenga, Gustavs. Remembering the common past. Livonia as a lieu de mémoire of the Teutonic Order in the Empire, in Selart, Anti; Thumser, Mathias (eds). Livland - eine Region am Ende der Welt? Forschungen zum Verhältnis zwischen Zentrum und Peripherie im späten Mittelalter. Köln; Weimar; Wien, 2017. (Quellen und Studien zur Baltischen Geschichte. Bd 27). Pp. 347-370.

Strenga, Gustavs. Remembering the dead: Collective memoria in Late Medieval Livonia. PhD Thesis, Queen Mary University of London. 2013. 274 p.

Tamm, Marek. Communicating crusade. Livonian mission and the cistercian network in the thirteenth century, in Ajalooline Ajakiri. Vol. 129/130. Tartu: University of Tartu Press, 2009. Pp. 341-372.

Tamm, Jaan. Residences of abbesses in Estonian monastic architecture, based on the examples of the St. Michael's cistercian convent in Tallinn and the Brigittine convent in Pirita, in Baltic Journal of Art History. Vol. 2. Tartu: University of Tartu Press, 2010. Pp. 63-95.

Tamm, Marek. The Livonian crusade in Cistercian stories of the Early thirteenth century, in Nielsen, Torben K.; Fonnesberg-Schmidt, Iben (eds). Crusading on the edge: Ideas and practice of crusading in Iberia and the Baltic region, 1100-1500. Turnhout: Brepols Publ., 2016. Pp. 365-389.

Teplouhova, Ilona. Sieviešu zīmogi un sieviešu attēlojums Livonijas vaska zīmogos [Women's seals and depiction of women in Livonian wax seals], in Latvijas Universitātes Žurnāls. Vēsture. Rīga: LU Akadēmiskais apgāds Publ., 2018. Vol. 5. Pp. 53-66. (in Latvian).

Urban, Willam; Smith, Jerry C. (eds). The Livonian rhymed chronicle. Chicago: Lithuanian Research and Studies Center Publ., 2001. 134 p.

Wüst, Marcus. Studien zum Selbstverständnis des Deutschen Ordens im Mittelalter. Weimar: VDG Publ., 2013. (Quellen und Studien zur Geschichte des Deutschen Ordens. Bd 73). 333 p. 